\title{
LA SEGURIDAD EN LA CADENA AGROALIMENTARIA DE LA CARNE: PROBLEMÁTICAS, ESTRATEGIAS Y POSIBLES SOLUCIONES PRE-FAENA
}

\author{
Frizzo, L.S. ${ }^{1,2} ;$ AstesanA, D.M. ${ }^{1} ;$ SOto, L.P. ${ }^{1,2} ;$ Blajman, J.E. ${ }^{1 ;}$ \\ ZBrun, M.V. ${ }^{1,2}$; SignorinI, M.L. ${ }^{2,4}$; MARTI, L.E. ${ }^{2} ;$ SequeIRA, G.J. ${ }^{2}$ \\ \& ROSMINI, M.R. ${ }^{2,3}$
}

\begin{abstract}
RESUMEN
En la Cumbre Mundial sobre la Alimentación, celebrada en Roma en 1996, se estableció que existe Seguridad Alimentaria cuando todas las personas, en todo momento, tienen acceso físico y económico a suficientes alimentos inocuos y nutritivos para satisfacer sus necesidades y preferencias alimentarias para desarrollar una vida activa y sana. Desde aquella fecha se ha trabajado intensamente para que esa definición se haga realidad. No obstante siguen siendo números los episodios en los que la seguridad de los alimentos falla y se afecta la salud y el bienestar de las personas, incluso hasta la propia vida. Surge entonces la pregunta: ¿cuáles son los factores que facilitan la aparición de las causas que producen los fallos en la seguridad alimentaria? Son numerosos y variados los factores que predisponen la aparición de los fallos en la seguridad alimentaria, no todos se presentan al mismo tiempo y, en general, están directamente asociados a las condiciones sociales que se imponen en cada región geográfica. Esta diversidad asociada a la cultura, el desarrollo económico y la accesibilidad a las diferentes formas del conocimiento, facilitan que los fallos se produzcan sin distinciones de poder adquisitivo, estrato social o región geográfica. Toda la población está potencialmente expuesta a ser víctima de un fallo en la seguridad de los alimentos que consume. El origen del problema radica en el complejo sistema de provisión de alimentos que impera en la actualidad, en el cual el consumidor es un actor pasivo del proceso de obtención, transformación, preparación y fiscalización de la calidad de los alimentos que ingiere. Toda la responsabilidad, de la calidad y la inocuidad del alimento, descansa en una cadena productiva y en los manipuladores que intervienen en cada uno de los eslabones. La educación y la capacitación específica de los manipuladores, así
\end{abstract}

\footnotetext{
${ }^{1}$ Laboratorio de Análisis de Alimentos, Instituto de Ciencias Veterinarias del Litoral, Consejo Nacional del Investigaciones Científicas y Técnicas (ICIVET-CONICET/UNL);

${ }^{2}$ Departamento de Salud Pública, Facultad de Ciencias Veterinarias, Universidad Nacional del Litoral;

${ }^{3}$ Facultad de Ciencias Agropecuarias, Universidad Católica de Córdoba;

${ }^{4}$ Consejo Nacional de Investigaciones Científicas y Técnicas, Estación Experimental Agropecuaria Rafaela, Instituto Nacional de Tecnología Agropecuaria, Ruta 34 km 227, (2300) Rafaela.

Manuscrito recibido el 6 de diciembre de 2013 y aceptado para su publicación el 24 de febrero de 2014.
} 


\section{Frizzo et al.}

así como el desarrollo de estrategias de prevención e intervención en cada uno de los eslabones de la cadena agroalimentaria constituyen las fuerzas de control más eficaces para lograr la seguridad de los alimentos. El estudio de las características especiales de cada cadena, en particular sus factores de riesgo potencial frente a los agentes nocivos específicos, resulta esencial para el desarrollo de estrategias de prevención y remediación sustentadas en el conocimiento científico. Estas estrategias se deben diseñar a partir de las condiciones de producción, cuidando la sustentabilidad de las fuentes productivas y compatibilizando la producción con el cuidado del ambiente natural. Resulta, además, determinante la participación y compromiso de todo el personal involucrado en los encadenamientos productivos lo cual se podrá lograr si, a través de la formación, los manipuladores comprenden la complejidad del sistema productor de alimentos y el enfoque de cadenas productivas. En esta revisión se plantea la problemática de la Seguridad Alimentaria, enfocándolo desde una visión sistémica y de procesos que deben ser diseñados y desarrollados con una misma meta: la inocuidad alimentaria. Los argumentos se sustentan mostrando los resultados obtenidos en trabajos de análisis de riesgos realizados en distintas cadenas productivas de alimentos y los resultados obtenidos en distintas estrategias de intervención en diferentes eslabones de las cadenas agroalimentarias.

Palabras clave: inocuidad de alimentos, seguridad alimentaria, patógenos transmitidos por los alimentos, estrategias de intervención pre-faena

\section{SUMMARY}

At the World Summit on Food Security held in Rome in 1996, it was established that food security exists when all people, at all times, have physical and economic access to sufficient, safe and nutritious food to satisfy their dietary needs and food preferences for developing active and healthy life. Since that time, hard work has been realized to make that this idea can be realized. However there are many episodes in which food safety failure and the health, wellbeing of people and even the life itself are affected. The question then arises: what are the factors that facilitate the emergence of failure causes in food safety? Factors that predispose to failures on food security are many and varied. These factors do not occur at the same time and, in general, are directly linked to the social conditions that prevail in each geographic region. This diversity related to culture, economic development and accessibility to different forms of knowledge, facilitate the failures occur without distinction of purchasing power, social status or geographic region. The entire population is potentially exposed to be a victim of a failure in the safety of food they consume. The origin of the problem lies in the complex food supply system that prevails today, in which the consumer is a passive actor in the process of obtaining, processing, preparation and monitoring of the quality of the food. All responsibility, quality and food safety rests in the productive chain and handlers involved in each of the links. Education and training of handlers and the development of prevention and intervention strategies in each of the links in the food chain are the most effective control forces to achieve food security. The study of the special characteristics of each chain, particularly its potential risk factors caused by specific agents, is essential for the development of prevention and remediation strategies grounded in scientific knowledge. These strategies must be designed based on the natural conditions of production, taking care sustainability of production 